\title{
Kumyk Language
}

National Cancer Institute

\section{Source}

National Cancer Institute. Kumyk Language. NCI Thesaurus. Code C153991.

A T urkic language spoken by the Kumyk people of the Dagestan, North Ossetia, and Chechen republics of the Russian Federation. 